\title{
State Versus Democracy in Thailand: Winners and Losers in a Develop- mental Context
}

JOHANNES DRAGSBAEK SCHMIDT

The present article is divided into four parts. ${ }^{1}$ The first part deals with the theoretical and conceptual framework for debating the role of the state in a developmental perspective. The second part consists of an empirical analysis which emphasizes the role of the state in Thailand and in the context of democracy and democratization at the regime-level, civil society and the interlinkage with external factors. The third part of the article provides a brief comparative perspective on the events in 1973-1976 - the period where popular forces toppled an authoritarian regime - and the latest events in 1992 where the Suchinda junta was forced to resign. ${ }^{2}$ Finally, some tentative prospects on state and democracy in the Thai context are offered.

Due to their dynamic growth in the last few decades, the question of analyzing the development of Southeast Asian countries has caught the attention of scholars. Of all the countries of the region, Thailand offers, with its economic results and political evolution, a showcase which can contribute to a better understanding of development processes.

In their bestseller Megatrends Year 2000, John Naisbitt and Patricia Aburdene argue that Thailand, along with South Korea, Taiwan, Hong Kong and Singapore, ought to be considered East Asia's fifth dragon. $^{3}$ Asian as well as Western international economists and investors hail Thailand as the next member of the exclusive club of Newly Industrializing Countries (NICs). The Asian Wall Street Journal describes "the Thai stock market as one of the world's hottest," and the International Herald Tribune regularly publishes special features about Thailand's economy as one with the highest 
growth rates in the world. This is indeed exemplified by the following statistics: from 1965-80 the average annual growth rate of GNP was 7.2 percent and during the international recession period from 1980-90 the annual GNP growth rate was 7.3 percent. ${ }^{4}$ There has been no negative growth since 1958 when it was plus 3 percent. Thus, growth has been about 7-8 percent yearly and only on three occasions did it drop to 5 percent (1971-72, 1982 and 1985). ${ }^{5}$ Thailand's GNP in real terms rose from US\$ 4 billion in 1965 to US\$ 41.7 billion in 1986 .

Thailand's economic success is based on low wages and access to a huge reservoir of cheap labour, thus offering a favourable climate for foreign investment. Simultaneously, in comparison to most other Southeast Asian countries, personal freedom is claimed to be more developed. For investors, the question of political stability is as important as economic factors. Despite insurgency and occasional violent protests, some of the ASEAN nations have been ruled by long-lasting regimes - Lee in Singapore, Suharto in Indonesia and Marcos in the Philippines. Only in Thailand have governments been short-lived and investors seem to be accepting that even with changes of government brought about by coup d'etat "there is little threat to investment." ${ }^{16}$ Furthermore government expenditure has moved away from regional and rural development in the direction of creating a suitable environment for major industrial expansion. This has lead some observers to claim that in the rush to industrialize "Thailand seems determined to become a NIC. With that conventional objective, it is ignoring its greatest potential services. Thailand could be the first country to bypass industrialization completely and evolve from an agricultural economy right into a service economy, a SSE - Straight to Services Economy. ${ }^{18}$. The former president of the National Economic and Social Development Board (NESDB), Dr. Snoh Anakul, has a more modest definition of the "Thai Miracle" and coined the acronym NAISE, which stands for Newly Agricultural and Industrialized Service Economy.

On the surface the Thai economy appears as a sunshine example and showcase of how an open liberal economy with emphasis on market forces strengthens economic growth as measured in macroeconomic terms. Furthermore, the lesson for other developing 
countries is related to the role of the state and other political factors; i.e., the apparent significance of a non-interventionist laissez-faire economic policy-making while maintaining a soft authoritarian and developmental perspective based on coercive and incorporative capacities.

In an address to the US Congress the Thai ambassador to Washington, Kasem S. Kasemsri, explained that Thailand is currently in a difficult structural transformation process of trying to develop a harmonious society. For the first time ever, the value of Thailand's export of manufactured goods exceeds the level of agricultural output. This process is reflected in a high level of urbanization and structural changes in the rural sector:

This also means greater demands on the government to provide social services to this mass population and to ensure that rapid economic growth proceeds rapidly enough to prevent the revolution of rising expectations from undermining the traditional foundation of Thai society. This is the raison d'être of all these five-year plans. The sixth of these plans ... calls for restructuring the Thai economy toward more industrialization led by exports. This is the traditional route of past success by those four Asian "tigers" - Taiwan, South Korea, Singapore and Hong Kong - all of which emulate Japan, the greatest economic trailblazer of Asia. In pursuing a similar strategy, Thailand now finds herself flying after these countries in a "flying geese formation", to borrow the Japanese term for these Asian NICs, right into the walls of U.S. protectionism. ${ }^{10}$

These remarks denote the importance of the concept of the capitalist developmental state developed by Chalmers Johnson in his study of Japan as having been the model for South Korea and Taiwan. It also raises the question, whether similar elements of state policymaking are to be found in the Thai context, ${ }^{11}$ i.e., a specific industrialization strategy as emphasized in the Japanese model. ${ }^{12}$

Johnson argues that in the Japanese variant of capitalism, "markets are emphasized as a source of growth rather than of shortrun efficiency, and a primary role of government is to supply incentives to promote growth through markets. The perspective 
motivating Japanese policy is explicitly dynamic and developmental. From this perspective, the competitive advantage of a nation's producers in world markets is created by policy rather than given by immutable resource and technological endowments. ${ }^{13}$

The central element of this theory, is not that the state intervenes because all states do. The question is, how does this intervention take place!

There is no doubt that Thailand is among the fastest growing industrializing economies ever recorded and that it is politically characterized by soft or quasi-authoritarian structures. Taking a combined look at the developmental state approach and Robert Wade's notion of "a guided market economy,"14 which in fact criticizes Chalmers Johnson for putting too much emphasis on institutions and bypassing the role of the state, an important question emerges: Has the state in Thailand the same kind of autonomy in economic policy-making, which is found in Japan, South Korea and Taiwan, or are societal and market forces merged with the state as in Indonesia? What are the obstacles to a democratic regime-form, and democratization from below?

\section{Theories of State and Democracy}

It has not yet been possible to establish an adequate theory explaining the economic, political, social or cultural pre-conditions required for the advancement of democratic development in different societies.

Nevertheless, one of the most distinctive political phenomena on the global scale has been a movement from authoritarian to more democratic regime-forms in the last $10-20$ years. This has been observable not only in the former USSR and Eastern Europe, but also in Third World societies such as Taiwan, Brazil and number of African states. ${ }^{15}$ Accordingly, the "transition to democracy debate" has attracted the attention of political scientists as well as policymakers.

In this paper it is suggested that the transition to democracy, at least in the case of Thailand, is determined by state control rather than by the forces of civil society or the business sector. 
Democracy and democratization as suggested in this article are connected with the state level in the following four ways: ${ }^{16}$ First, democracy is related to the regime-form. Second, the state is related to the mode of production and macro-economy in general, both at the national and international level. Third, state power understood as the ruling classes' dominance of the political, ideological and cultural levels, and finally, state form as the hegemonic relationship inside the dominant bloc or class which possesses state power. At the same time the question of the functioning of the state applies to the extractive capacity, coercive capacity, incorporative capacity, and the capacity to manipulate the operative elements in the (macro)economic system. These capabilities, I suggest, have a great influence on the distribution of political power as they are determining the strength of the state in the domestic and international context as well.

However, the problematique of capacity versus autonomy of the state is an empirical matter which is hypothesized to be one of the most important determinants with regard to the regime-form and as such linked to the problem of democracy versus authoritarianism. The same question has relevance for the level of the democratization process at the actor level as mentioned above.

The framework for the empirical study of state and democracy must include a tripode historical analysis of the international aspect, the capacity of the state and a description of the emerging classes.

\section{The Historical State and Political Processes in Siam}

The questions to be answered are why did Siam develop mainly along anti-democratic lines and what is the explanation for the nonparticipation of the population in the societal and the production context? Allegories like "land of smile", and the anthropological term of the "loosely structured social system", ${ }^{17}$ have been used as explanations for a widely claimed specific political culture in Thailand. Similarly Chai-Anan asserts that independence meant that the country did not experience the imposition and transfer of institutions from the West that took place in many developing 
countries. ${ }^{18}$ To answer these questions and examine these statements we must turn to history. In 1971, Norman Jakobs made a comparative study between Japan and Thailand. Like Thailand, Japan escaped colonialism. The two countries share a high degree of cultural homogeneity and a strong national identity. ${ }^{19}$ The way both countries prevented direct colonization was, as I will show in the following with emphasis on Thailand, identical. In Japan the system of ministries and agencies came into being well before the political parties, the constitution, and the parliament. As Jakobs argues, as different from the United States, "these ministries were not created to be 'civil servants', or to provide regulation of private concerns, or to supply jobs for party loyalist, but rather to guide Japan's forced development in order to forestall incipient colonization by Western imperialists. ${ }^{120}$ The administrative and bureaucratic praxis was characterised by "vertical administration ${ }^{21}$." Interestingly, many observers at that time were sure, that "Siam would develop while Japan would not."122

It is well documented that capitalist economic and social development in Siam started with the opening to international trade in 1850, resulting in the formation of important production factors, such as financial capital, labour and management. The expansion of agricultural output was mainly due to an increase in planted area. Revenue derived from domestic production and from exports were, however, mostly remitted out of the country, thus implying that the Thai economy at that time was likely to become an economic colony of European and Western countries. ${ }^{23}$ The most important institutional import in the realm of colonialism, however, is indicated by Hanks, "The formation of the Thai state had to await the nineteenth century when both the idea and reality of a nation state was introduced from abroad."24

In another comparison between the Meiji reconstruction in Japan and the Chakkri reforms in Siam, Benedict Anderson argues that especially on one point the response of Siam to the colonial threat was quite different from that of the Japanese:

Squeezed between British Burma and Malaya, and French Indochina, he [King Chulalongkorn] devoted himself to a shrewd manipulative diplomacy rather than attempted to 
build a serious war machine (A Ministry of War was not established until 1894). Chulalongkorn tried to emulate the state and development model along the lines from the colonial 'beamtenstaaten' in Dutch East India, British Malaya, and Raj. $^{25}$

Furthermore, the Chakkri reforms meant the official abolishment of the Sakdina system ${ }^{26}$ and the rationalizing and centralizing of royal government, eliminating traditional semi-autonomous tributary statelets, and promoting economic development along colonial lines. ${ }^{27}$ Together with the strong centralization of the state apparatus a powerful army was developed whose primary function was to maintain internal stability and control revolts against internal colonialism as well as other reactions to the centralizing reforms. ${ }^{28}$ The dominant position the military has played in Thai politics since the 1932 coup can be traced back to the Chakkri reforms. ${ }^{29}$

The most important example of how the colonial administration functioned in Bangkok was Chulalongkorn's decree on massive import of single, young Chinese males. The Chinese were meant to be a sort of buffer between the King and the nobles on one side and the rest of the population on the other. As Wyatt notes, "In 1910 there was not one, but two Siams" ${ }^{\prime 30}$ and the Chinese became the "pariah entrepreneurship." 31

The main targets of the 1932 coup were the old ruling monarchy and the internal private sector groups, mostly of Chinese or SinoThai origin, who generally lacked a basic relationship to the Thai population. The soldiers and civilians behind the coup understood this political act as the first real break with colonialism, which was symbolized in "The National Anthem after the revolution which says Thailand enjoys complete sovereignty because of the revolution." ${ }^{132}$ The economy was to be delinked from Western influence and a welfare state "directing the economy towards meeting national needs" was to be established. ${ }^{33}$ In other words a reassertion of Thai interests with an anti-foreign element.

However, today the importance of the ethnic factor - is not to be denied as most Thai banks are owned by the descendants of immigrant Chinese. Similarly, the Chinese serve as points of entry into the Thai market for Japanese firms. ${ }^{34}$ Indeed, the dominant 
position the Chinese have played in the Thai economy together with the military's dominant position in the state apparatus can be traced back to the reforms initiated by the Thai king. This had grave consequences for the development of the country's politics.

The view of Siam, and later Thailand, as a nation with a specific peaceful political culture, has been one of the explanations as to why there has been no break with autocratic rule in Thailand. It is known to be erroneous. Various sources have pointed to occasional outbursts of violence throughout the past on the part of the state and the army. Hewison and Tambiah provide a picture of history with peasant and worker rebellions, strikes, ethnic and tribal upheavals brutally suppressed. ${ }^{35}$

The military violence against the democratic movement during the May 1992-events in Bangkok was not the first example of statecreated repression and intra-rivalry among the bourgeoisie, politicians and the Thai military. Struggles among farmers in the rural areas and crude oppression on the part of the state since the democratic period from 1973 to 1976 have likewise been documented. But because of the difficulty to monitor the specific events and find witnesses and sufficient source material it remains, however, to be shown exactly who were the forces behind each specific event. ${ }^{36}$

The following points are of importance: Because of the lack of a total break with absolutism, civil society is still very weak. Consequently Thai political culture is characterized by a population showing a strong degree of identification with the bureaucracy, the military, the state (which is actually part of the military and vice versa), the nation, the king, the monarchy, and religion. It provides the state and associated institutions with a monopoly of legitimacy rarely found to such an extent elsewhere. Moreover, perceived problems of insurgency and threats to national security have strengthened military and paramilitary social forces and strongly influenced public policy and forms of social control. ${ }^{37}$

The model of "internal colonialism" (or center-periphery relations) in the late nineteenth century has been rejuvenated since the early 1960 s under the name of national security and development. ${ }^{38}$ The weak development of civil society combined with the centerperiphery relation has meant that long-term projects of 
constitutionalism and parliamentary democracy have largely been rhetorical, or have been initiated only to be undone and then restarted after periods of more intense authoritarian rule. The extreme polarization between center and periphery has resulted in a social transformation. As Suchart notes, "Bangkok and the Central Region earned more than half the country's GDP throughout the period 1961-1984. Bangkok alone increased its share of GDP from 22.7 in 1961 to 36.3 percent in 1984, at the expense of other regions. ${ }^{139}$ Over 75 percent of corporate tax revenues come from the metropolitan region. Almost every per capita index of progress telephones, light bulbs, doctors, hospital beds, motor cars and the like - show a favoured Bangkok that, literally, puts the rest of the country to shame. ${ }^{40}$

Bangkok has a more complex social structure than is found elsewhere in the country. It retains remnants of the old hereditary royalty and nobility, of which some members are extremely wealthy as a result of ownership of large tracts of real estate in the greater Bangkok metropolitan area. Today, however, two elites - the bureaucratic-military body which controls the government and the capitalist class which controls the major industries, trading firms, and financial institutions - run the country. Although the vast majority of the capitalist elite members appear to be of Chinese descent, because of assimilation and personal identification as Thai, they no longer possess the ethnic distinctiveness of their ancestors. Similarly, while most members of the bureaucratic-military elite are of Thai origin, an increasing number (perhaps as many as a quarter to a third) are Sino-Thai. These people no longer define their interests in the same ethnic terms as did their predecessors in the pre-World War II period. But regardless of the decline of ethnic tension and considerable intermarriage between the bureaucraticmilitary and capitalist elites, and although many individuals belonging to the former sit on the board of corporations owned or managed by members of the latter, these two elites still have distinctive interests that lead to periodic conflicts between them. Debates over the devaluation of the Baht in the 1980s provide such an example. Although business leaders supported devaluation because they thought it would stimulate exports and encourage the purchase of domestic products over imported goods, many in the 
bureaucracy and especially in the military opposed it because such a measure would increase the cost of imported arms, considered crucial to maintaining power, to an almost prohibitive level. ${ }^{41}$ Deyo's study helps to explain the underlying mechanism which has been used to exclude the farmers and workers from participating in political power relations. At the level of decision-making he identifies this pattern as developmental paternalism said to be the structural foundation for East Asia's industrialisation:

The political and economic strategies of East Asian elites draw moral strength from two closely related sets of values. The first of these, centered on paternalism, invokes the moral authority of leadership that both defines and pursues national (vs. sectoral) interests through bureaucracy and public pronouncement. The second, asserts the efficiency of such leadership through its proven material consequences for the public wealth. Economic development is the chosen measure of national welfare and thus a crucial basis for political legitimacy. Development paternalism, the composite of these two legitimating principles, justifies political exclusion and authoritarian rule as necessary for continuing high levels of growth. Alternative legitimating principles are effectively excluded from the moral domain of public discourse. ${ }^{42}$

Even though Deyo's analysis concentrates on Taiwan, Hong Kong and Singapore, the two main elements of his "developmental paternalism" concept apply equally to the case of Thailand. A number of studies by Thai scholars confirm this point. ${ }^{43}$ It is developmental paternalism which provides the legitimizing basis for the exclusion of civil society and justification for the periods of massive repression, evident before 1973 and after 1976.

Under such conditions, legitimate or claimable space for more democratization and alternative or participatory approaches to development has been impossible. Oppositional ideas and forms of organization have been severely restricted. This is especially the case for the poor and the disadvantaged rural producers, who form the majority of the population.

The specifity of Thai political and economic life is connected with the rise of the ethnic Chinese together with the emergence of a 
group of civil-military bureaucrats. The former originally fulfilled the role of agents for royal capital accumulation and later "pariah entrepeneurs." The bureaucrats emerged as a by-product of the creation of an absolute state and as substitute for the missing Thai bourgeoisie. These two groups formed the layers behind the evolution of a tripode structural collaboration between the Chinese business elite, the Thai civil-military bureaucracy and foreign capital. The alliance arose as a result of the Chakkri reforms.

\section{The Long Wave of Paternalism and Developmentalism}

The first military coup in Siam, which changed the name of the country to Thailand in 1932 and introduced a flag and a national anthem, is normally referred to as "the revolution." The coup ushered in an era of rule by bureaucrats without subjection to the authority of a traditional monarch nor to the controls of formal institutions legitimized by the idea of "popular sovereignty". This problem of legitimacy plagued political leaders and has been the main characteristic of Thai political culture ever since.

Thus concepts like nation, religion, monarchy on the one hand and constitution and democracy on the other compete for position as legitimizing symbols. They have been used as circumstances dictate by the same leaders at different times to justify bureaucratic and military dominance of the polity. ${ }^{44}$ But the most important result of the 1932 coup was the expansion of profit making activities. ${ }^{45}$ After the 1932 revolution the state began to promote an industrial sector with the goal of establishing a self-sufficient economic system. However, in reality the industrial sector was first created after the 1958 coup on the basis of an alliance between the influential Chinese business community and the political leaders of the coup.

The initial main revolutionary target of the 1932 coup was the monarchy and groups in the private sector mostly of Chinese origin, who generally lacked a basic relationship with the Thais. ${ }^{46} \mathrm{~A}$ constitution and a parliamentary system of government were adopted. However, this constitutional idealism gradually eroded 
into formalistic constitutionalism subsequently reflecting more accurately a shift in the regime-form from absolutism to "Thai-style democracy". ${ }^{47}$ Hence, the 1932 revolution - and this was to be the pattern of subsequent coups as well - far from being a democratic or a mass movement "was the replacement of one oligarchy by another." ${ }^{148}$ In fact, it was a change in the formal government structure, i.e., a revolution within the ruling elite. In consequence the monarchy was not abolished. Its powers were subjected to constitutional limitations, and representative institutions were established. But since the king continued to "reign", this most important symbol of legitimacy was retained and as it has been argued by one observer, "those who exercised power after the coup did not have to face the problem that most leaders of coups d'état have: establishing their legitimacy in the minds of that portion of the population that is politically conscious." ${ }^{149}$

The next important coup to be mentioned, is the "Sarit revolution" in 1958. Its aim was to overthrow the traditional political system inherited from the 1932 revolution and to seek modernization and economic progress on the basis of Thai values and culture. ${ }^{50}$ The "thaification" of the political system meant the promotion of the symbolic triangle based on the three ideals - King, Religion and Nation, that is to say a reinstatement of the authority of the king. As Thak notes, "In his concept of the modern Thai state, the king was to be recovered as symbolizing the spirit of the people, and their past and their tradition; Buddhism was to be embraced by all as the source of social morality and ethics. "51 The objective of the regime was to pursue a coherent national development strategy involving an increased role of the state in promoting this particular kind of development through the formation and implementation of various reformist policies and programs. ${ }^{52}$ In this context Sarit held Western constitutional democracy to be inappropriate because it was an obstacle to economic development. ${ }^{53}$ Hence, the strategy was meant to enhance the regime's ability to function as a paternalistic system: the final goal of development and modernization was seen as essentially facilitating administration of society. ${ }^{54}$ It happened on behalf of participation, political mobilization, and the building of new political institutions. 
The goals of the new development policy and the new role of the state could only be accomplished through intensive repression of the population. ${ }^{55}$ This was very much in line with the interests of the Sino-Thai bourgeoisie and as a representative of the Bangkok Bank said in a press release:

We have found from past experience that whenever trade unions are allowed ... they fall into the hands of undesirable elements who use the trade unions as a tool to subvert the democratic working of the government. Therefore, for security reasons, it has been found necessary to prevent the functioning of trade unions. ${ }^{56}$

The conclusion of the bank was, that the best mechanism to prevent trade unions was through state coercion.

Interestingly, the new role of the assimilated Chinese bourgeoisie was a reversion of its former position, as a buffer group between the monarchy and the people, to that of a kind of go-between between bureaucratic and foreign capital. ${ }^{57}$ As in 1932 the Sino-Thai played the overwhelmingly dominant role in internal business activities and as the link to the world market through connections in Hong Kong, Singapore, Taiwan, and China, not to mention the Chinese communities in the United States and Europe.

Consequently, the underlying cause of the nationalist economic course, which began with the 1932 coup d'état, was not internal factional rivalry; ${ }^{58}$ on the contrary it was the result of class struggle, with ethnic and nationalist aspects, between the Thai civil-military bureaucracy and the Sino-Thai bourgeoisie.

Historically, the mixture of class, ethnic and nationalist conflicts brought about momentums of thaification versus alliances between the two groups. The anti-Chinese thaification policies created in reality the basis for a triple alliance. This construction can be defined as a symbiotic but asymmetric relationship between the two internal compradors and their foreign connection. As Mike Douglass notes:

With a benevolent external economy, the dominant and almost exclusive Chinese merchant class was able to undermine the posture of economic nationalism by assenting 
to the inclusion of Thai military and bureaucratic elites on the boards of their trading companies. Instead of accumulating wealth through the construction of state-run enterprises, the Thai political elites could claim handsome incomes as "directors" of Chinese-run businesses which prospered in an open economy. ${ }^{59}$

It is the class, ethnic and nationalist rivalry which has been the underlying reason for the subsequent military coups and authoritarian rule. The paradoxical result is that government officials sit on the boards of directors of private enterprises while Chinese serve in management of state enterprises and government monopolies originally established to keep some economic activity out of their hands. ${ }^{60}$ What is argued here is that one of the most important reasons for the anti-democratic development of Thai society, has been the exclusion of the indigenous Thai business sector. The military has been the vanguard of Thai nationalist values, not only in order to fight the internal and external communist threat but also as a substitute for the non-existing Thai bourgeoisie. The two principal contending forces of Thai society post-1932 have been the military dominated state bureaucracy and the Chinese business sector.

\section{External Pressures on the Regime-form, State Capacities and Policies}

As mentioned earlier, the Thai Kingdom and the state historically relied on the big powers to maintain the country's formal independence. Sukhumband referring to Girling's precise observation, ${ }^{61}$ makes the point that the patron-client structure of internal Thai politics is paralleled by a preference for a similar relationship in foreign affairs, first with the British against the French, next with Japan during the World War II, and finally, with the United States. ${ }^{62}$

Among the international determinants American influence is the single factor which gives coherence to the social, economic, and political history of Thailand since World War II. ${ }^{63}$ The Thai military 
regimes became one of the significant supports behind US strategy against communism in Northeast and Southeast Asia. ${ }^{64}$

However, once again the Japanese state and zaibatzu have replaced the Americans in terms of economic influence. Especially since the late 1980s and the beginning of the 1990s, the Japanese economic impact and subsequent political and cultural influence have grown tremendously not only in Thailand but in the whole area of Northeast and Southeast Asia. ${ }^{65}$ As Masashi Nishihara, attached to the Japanese Defence Agency, notes in a strictly personal statement:

Asians often argue that Japan would protect its extensive economic interests in Asia by force, if it were compelled to ... Asians suspicious of Japanese behaviour are contradicting themselves. If the Japanese were to use force to protect their economic interests in Asia, the most effective way to check Japanese "militarism" must be for Asian governments to reduce Japanese economic presence in their region. But in practice they call for more economic aid and investment from Tokyo. Yet, a reduced Japanese economic presence certainly means less aid, less investment, and less trade, which in turn would adversely affect the economic prosperity of the region. ${ }^{66}$

Adjusting to Japanese neo-mercantilist interests is reflected in Prime Minister Chatichai's plan to convert resource-rich Indochina from a "battlefield into a trading market." The Thai military leaders want to establish similar exploitative relations with Cambodia as they have with Burma. ${ }^{67}$ The Thai aspiration to regional leadership was reflected in the Prime Minister's "New Look Diplomacy" which has drawn some reservation in other ASEAN capitals. As Um notes, "Much of the concern, however, is rooted in Chatichai's own penchant for sweeping and controversial rhetoric. One example was his proposal for a joint Thai-Japanese naval exercise in the South China Sea". ${ }^{68}$ Already in 1989 the major antagonism between Chatichai's "no problem" attitude promoting Sino-Thai big business interests at the expense of the military and the technocrats, as exponents of genuine Thai interests, was highlighted through various reports in the press and journals. ${ }^{69}$ 
As part and parcel of American long-term aims in East Asia, Thailand from the 1960s on became a cornerstone of this strategy fulfilling the function of a buffer state between the free world and Asian communism. The hegemonic role of the military within the state contributed to the creation and expansion of some successfully coherent developmental policies in the post-World War II period. But this was not an autonomous evolution. In fact, the military was institutionalized by American aid, and the subsequent capacities of the state agencies were designed in the shadow of American Cold War foreign policies. ${ }^{70}$

Apart from the US direct predominance through its military assistance, the World Bank and other multilateral agencies also exerted influence on Thai politics. Grit has compared the authority of the World Bank on the regime-form, the state, and the subsequent development policies to the consequences of the Bowring Treaty in the middle of the nineteenth century. ${ }^{71}$ The World Bank and the United States were, in the case of Thailand, "indeed inseparable." ${ }^{172}$

Aid, loans, and "policy recommendations", forced the Thai state to integrate with the world market. ${ }^{73}$ And what is more important, aid in the form of advice, became the mechanism of the World Bank to enhance technical dependency creating a decision-making process external to the peripheral state. This implied an important development strategy shift in the late 1970s from predominantly import substitution industrialization (ISI) to a policy of exportoriented industrialization (EOI) ${ }^{74}$ Paradoxically, another consequence of this change in development strategy and macroeconomic policies is that Thailand still lacks an effective system of "screening, negotiating, registering, and monitoring U.S. and any foreign direct investment activities. ${ }^{175}$ In the early 1980s, the IMF and the World Bank were instrumental in pushing Thailand, by means of Structural Adjustment Loans (SALs), to restructure its economy and reduce the budget deficit and put an end to government subsidies on public utilities and oil prices. ${ }^{76}$

The last example of technical dependency is connected with the crucial question of the missing land reform. Because of the World Bank's orthodox position on privatization, the Thai state and government have not been encouraged to extend the needed 
political intervention in the rural economy, and as one observer pointed out:

To permit and facilitate change in agricultural production, changes in the social structure and tenure patterns must occur. Most of Thailand's farmers do not own their land and, therefore, do not qualify for the bank loans necessary to stimulate these developments. Will the Thai government give the priority for finding these funds? And probably more important, will it be courageous enough to do this in opposition to the World Bank's orthodox dogma of "privatizing" at all costs. ${ }^{77}$

The essential problem, at least compared with the Japanese model, is the missing land reform.

Nester has provided an important insight with regard to the international influence during the period of the late 1940s through the 1960s, when Washington and Tokyo worked assiduously to reassert Japan's economic presence in Southeast Asia. In this dynamic triangular economic relationship, a division of labour was agreed upon whereby the United States would provide capital and high technology, Japan intermediate goods, and Southeast Asia raw materials. In these years, American embassies helped Japanese business obtain access to local markets while both American aid and Japanese war reparations were tied to purchases of Japanese goods and services. ${ }^{78}$ By the mid-1970s, as the economic development continued to advance, Japan replaced the United States as the region's most important source of trade, investment and aid. Walter Arnold shows that "Japanese economic relations cannot be perceived as politically 'neutral'. Instead, they must be seen as instruments of influence, power and possibly domination. ${ }^{179}$

The bulk of foreign direct investment (FDI) from Japan and the United States until the beginning of the 1980s had gone into importsubstituting industries. Thereafter a substantial increase of net FDI inflows to Thailand went to the export-oriented sector. In Thailand, companies with foreign capital involvement are among the largest in the country. In the case of Japanese FDI a dependency is established with the enterprise in Thailand having to rely on the technological know-how and sometimes financial resources of the 
mother firm. The Japanese shareholders form a powerful group and maintain control of the company despite their minority shareholdings. ${ }^{80}$

The result of Thailand's integration into the world capitalist orbit has been a limited, externally determined, political and economic capacity and capability, which has created the conditions for legitimizing the authoritarian state. As Hewison has noted, "the supply of large loans and credits by international agencies and private transnational banks gives them a considerable stake in the direction of national development and provides international finance capital with a strong stimulus to influence development policies". 81

\section{State Capacity Versus Autonomy}

To promote economic growth a strong coercive state is necessary, and the incorporative mechanism at the ideological and political levels has so far functioned rather well. However, from 1973 to 1976 the state and the military loosened the grip allowing the necessary political space for a popular organization of social groups hitherto excluded from control over resources and regulative institutions. ${ }^{82}$ The resulting 1976 massacre recreated the developmental paternalism of the state, through what Turton terms "the genealogies of violence based on 'a climate of fear' in which violent attacks or death by assassination, rather than mere official rebuke or arrest, is a possible, ultimate sanction. ${ }^{183}$

Although the situation is complicated it seems to be certain that the dominant political and cultural matrix of King, Religion and Nation, while being the hegemonic ideological legitimation of the growth strategy, likewise will determine the necessity of authoritarian state policies to promote economic growth.

Corresponding to the arguments elaborated upon above, although external influences on the regime-form and subsequent development strategies have been important, the Thai state has played a major role in the domestic development of capitalist production. But the problem in the case of Thailand is that compared to the Japanese Model, as exemplified by MITI strategies in Japan or planning 
agencies in Korea and Taiwan, which focused on so-called "Sun Rise" industries through the implementation of coherent and rational industrial policies, the Thai state has not had the same capacity to rationalize its economic policies and implement the expected goals of any of the five-year plans. ${ }^{84}$

The relative weakness of the indigenous classes is reflected in the fact that the military and the bureaucracy have come to exert decisive control over the state apparatus. In general, the policies of repression of labour organizations, subsidies on food and fuel, protectionism of small sectors of the economy, investment in infrastructure and production have fostered the growth of a previously weakly developed indigenous capitalist class. The changes in the Thai economy over the last thirty years have been spectacular. But in terms of economic policy it was not before 1985, when Thailand shifted away from the protected, import-substitution strategy of the 1950s, and moved decisively towards export orientation that favorable results could be observed. ${ }^{85}$ Relatively developed industrial sectors have been established and exports have constantly increased. However, it is questionable whether these changes can be attributed to the development strategies per se. Rather the policies have to be seen in terms of "facilitating changes made possible by the development of the international economy." In this context the role of the military dominated state bureaucracy has been crucial as a mediator between international and Sino-Thai capital interests linked up in the triple alliance of state, Sino-Thai capital, and foreign multinational capital.

Generally speaking, the basic credo underlying the Thai state's reformist policy for the past two decades was - and still is - the facilitation of the growth of private industries and private enterprises through public expenditure (including international development aid and loans). ${ }^{87}$ The idea is to transform Thailand's traditional society into a modern industrialized economy in the mold of advanced Western capitalism. This can be observed in the accumulation strategies (ISI and EOI) followed by 1) the squeezing of Thai agriculture under the name of agricultural and rural development; 2) the disciplining of the Thai workforce under the justification of economic doctrines of maintaining a comparative advantage and a favourable climate for foreign investment; and 3) 
the opening of the Thai economy and society to foreign capital penetration and exploitation under the banner of industrialization and economic development. Thus, planning in a Thai context facilitates and legitimizes the development of dependent capitalism.

Basically, the neoclassical economic development model as well as Keynesian economic theories emphasize macro-economic growth and industrialization, with the support of the agricultural/rural sector, and growth is measured in terms of per capita income. This development framework is urban-biased and imposes "an economic versus noneconomic dichotomy, and de-emphasizes income distribution". 88

Authoritarian states may maximize their independence from society, but they lose capacity and ability due to their failure to mobilize public support because of too much stress on coercive means of control. Thailand is ruled by shifting, narrowly based regimes relying on substantial degrees of control. The result is that the state is dominated by powerful groups limiting state capacity. ${ }^{89}$ Thai governments come and go, but it does not seem to matter all that much, because the military and administrative structure remain intact. 90 Over the past four decades, the bureaucracy has been controlled through the assignment of military officers to crucial positions of authority over civilians and by a continual process of coopting bureaucrats to work amiably and effectively for the military regime. Thus the military has continually administered governmental affairs. ${ }^{91}$

Similarly, authoritarian policies of varying degrees are determined by the common interests of the triple alliance which means the SinoThai local big capital, the military and the bureaucrats in the state apparatus and foreign TNCs, multilateral organizations, core states like Japan, and to a lesser degree the United States.

Consequently, democracy in Dahl's definition has not evolved, neither at the regime level nor at the actor level because of the contradicting interests embedded in the state apparatus. The reasons for authoritarian rule are to be found in the policies of legitimizing weak state capacities at the overall macro-economic planning and implementation level. The high economic growth which on the other hand creates enough room for manoeuvre is legitimized through a combination of coercive and incorporative capacities, 
which have political, ideological and cultural elements. In short, high economic growth is a determining condition for the intervention of a weak state in economic affairs thereby giving it a strong capacity to manipulate and incorporate the hitherto excluded majority. ${ }^{92}$ The polity in Thailand is a cultural ethic entity, a nation state, based on the ideological triangle King, Nation and Religion as the legitimizing space and autonomy for political authoritarianism.

\section{Democratization From Below Against Thai Style Democracy From Above}

The above mentioned aspects are clearly illustrated in events from the period of October, 1973 to October, 1976, which is usually termed the "Democratic Spring of Thailand" where the legitimizing institutions of the state were eroded by the national popular elements on three levels.

First, because of the state squeeze on the majority of the population, i.e., the peasants. The unpopular rice premium was one of the cornerstones of the capacity of the state to extract resources from agriculture for industrial development. This policy instrument was geared toward nurturing the accumulation strategies of ISI and $\mathrm{EOI}$, and is quite obviously working against the interests of the rice farmers, who account for almost eighty percent of the entire population. For historical, political and cultural reasons the capacity of the state to implement the rice premium has undoubtedly been very effective as a means to achieve social peace in the urban areas but simultaneously it is one of the underlying reasons for the widespread poverty in rural areas. ${ }^{93}$ As such the rice premium has become the single most controversial policy issue in post-war Thai society. ${ }^{94}$ The attempt to diversify Thai agriculture through the rice premium policy, when associated with a bad harvest, by and large leads to a rice shortage, as was the case during 1972 and 1973. From June 12 to July 30,1973, rice exports were completely prohibited. In fact, the 1973 rice crisis, in which the city people had to stand in long lines in order to buy rice, became one of the key factors that contributed to the fall of the military regime in October 1973. 
The second factor is the external dominance in the form of growing Japanese influence not only in economic terms but also in the cultural and political spheres through conditions implied in Overseas Development Assistance (ODA) and other kinds of aid related measures. ${ }^{95}$ After the American defeat in Vietnam, the withdrawal of US troops from Thai territory left an exhausted home market, where the Sino-Thai bourgeoisie and the increasingly corrupt bureaucratic-military regime could not find outlets for the home production. When the Americans moved out the Japanese moved in, gradually coming to dominate the economy in collaboration with the military regime. The organizational nodal point of the popular forces became related to an anti-imperialist demand directed at both representatives of foreign domination and hegemony. These developments led to pressures on the state and the government to draft a democratic constitution.

Finally, it can be argued that the legitimacy of the politicocultural matrix as described above came to a critical point after two decades of martial law and dictatorial rule. The popular movement, with the students as the vanguard, rejected deep-rooted Sakdina values and ideologies and the inertia of parliamentary "Thai-style democracy" as well as the inefficiency of the bureaucracy. ${ }^{96}$ The crisis of legitimacy expressed itself through the breakdown of the dominant national politico-cultural discourse - paternalism. The reasons for this evolution were connected to what we have chosen to term the process of democratization from below and on the other hand the missing capability and capacity of state hegemony to implement coherence within the coercive and incorporative policies, which could have preserved the social and cultural persistence of the regime's legitimacy.

Regardless of the fact that all examples of democratization from below in Thailand had different contexts their thrust was directed at the state. This shows that the key question remains power over the various state capacities. But in accordance with the theoretical sketch the main point to be emphasized is indeed that the overthrow of the military regime should be seen as a move and a process of democratization from below which achieved a three year period (1973-76) with significant changes at the regime level. However, it did not change the state apparatus. Hence, the military 
dominated bureaucracy remained intact. And in fact, the result of the period of democratic Spring was a bloody and violent massacre in downtown Bangkok and the introduction of a new military regime.

In the beginning of the 1980s, the military introduced a new strategy. From then on it based its legitimacy on "Thai Style Democracy", an old concept with a new content. This new policy must be seen in relation to the introduction of Export Oriented Industrialization (EOI) together with growing state interventionism in all spheres of society and production. The new activities in the rural areas were named COIN, which stands for counter insurgency programmes against the armed Communist Party. Described as "development programmes" which include a proliferation of social surveillance and controls with "democracy" and "participation" as policy catchwords, the government strategy seems in effect to resemble the Indonesian state's New Order with a "floating mass strategy of preventing rural population from engaging in organized political activity. ${ }^{197}$

But it is not only the means of violence that are under the control of the military. Even though the IMF and World Bank "advised" Thailand to embark on a comprehensive privatization programme in 1984, in 1991 the process was still proceeding extremely slowly. As the Far Eastern Economic Review noted in June, $1991^{98}$ much of the recent progress in privatization had been carried out under the discredited government of Chatichai Choonhavan. Accusations of corruption over certain public-private ventures, together with a privatization tussle with the Electricity Generating Authority of Thailand (EGAT), set the scene for the February 1991 military coup which brought about Chatichai's demise as prime minister. The military's longstanding role in state enterprises is unlikely to diminish much in the near future. The military regards its influence on the boards of state firms as important for national security, as well as providing the military with access to benefits that would otherwise be unavailable for badly paid soldiers. Their boardroom presence is established both by tradition and legal right. Among the 20 state enterprises, 26 percent of board members are reported to be acting or retired military officers. Leaving aside the four state banks, which have no military representation, the figure rises to 32 percent. 
Board seats enable the military to find state-enterprise sinecures for retiring military personnel, to direct purchase contracts to military linked suppliers, and to award service contracts to friendly companies.

The military has institutionalized the means of mobilizing the masses in support of the government (when appropriate), individual leaders, the military's national security programme, etc. Some of these institutions are the Capital Peace Keeping Force, the Civil Affairs Centre, the Directorate of Civil Affairs of the Royal Thai Army, etc. Concerning these institutions Sukhumband Paribatra has argued:

These, together with other institutions and agencies directly controlled by or closely related to the military, such as the Senate, the Internal Security Operations Command (ISOC), the National Defence Volunteers and the Village Scouts, give the Thai armed forces a high degree of capability to conduct mass psychological operations, to instill what is euphemistically referred to as "a sense of responsibility" in the public consciousness, and indeed, to gain crucial or perhaps decisive support for the military when necessary and appropriate. For the latter such involvements are "legitimate" for there is no dividing line between national security, politics, government services and military affairs. To illustrate these institutional developments impressive figures of state expenses show that over one-fifth goes to the military."

In short, the military and the state have incorporated the population much more efficiently in order to strengthen the new politicocultural hegemony and social order. This is, paradoxically, a fulfilment of David Wilson's thesis that Thailand's development problem in 1962 was a matter of bringing the state machinery under some disciplining power. ${ }^{100}$ 


\section{Crisis and Control: a Comparative Perspective on October 1973 and May 1992}

On October 5, 1973, confrontations between the military and the National Student Center of Thailand (NSCT) culminated in front of the Democracy Monument in Bangkok when a student made a speech naming more than 100 prominent public personalities as signatories of a statement demanding a new democratic constitution. ${ }^{101}$

Prior to this culmination, a number of demonstrators had been arrested for inciting the public to rise against the government. The NSCT had organised boycott campaigns against Japanese products and protests against the control of the military over the rule of law, regularization, and constitutionalism. ${ }^{102}$ In the end, the NSCT decided to draft a constitution themselves. ${ }^{103}$ On October 14, which later became known as the "Day of Tragedy" or "Bloody Sunday", riot police and the students clashed in violent fighting and later on the army moved in. Many people were killed. ${ }^{104}$ Subsequently, the king stepped in to control the situation by asking Thanom, Prapas, and Narong to leave the country. Given the refusal of General Srivara, the army chief, to stand on their side they had no alternative left but to comply.

"The other revolution", as Girling calls these events, was indeed revolutionary in the sense that it started as an intellectual-based movement, but it came to deal with concrete problems and the conditions of the masses. It challenged the power structure of the privileged groups and it resulted in the release of economic and social forces which had taken shape during the past two decades. ${ }^{105}$

At the same time, it aimed at a complete break with the ruling political culture - paternalist developmentalism - and its deeply rooted Sakdina values and ideologies, i.e., the patron-client relationship in politics and economics, as well as in foreign affairs. On this basis, it is possible to view the movement, the NSCT, and other components as "a democratic force opposing elitist dictatorial rule and aspiring to develop a new democratic and creative political culture."106

However, the 1973 coup could also be interpreted as a triumph for those elements of the Sino-Thai business sector who, in fact, 
used the student movement and popular resentment as a visible front for the realization of their own interests. For a couple of years after the 1973 revolution, there was a wave of liberal optimism, which was ultimately undermined by the bloody coup of 1976 . Interestingly, the amount of foreign investment declined considerably during the 1973-1976 period. ${ }^{107}$ On the other hand, the three year period of "open politics" made the unhampered growth of trade unions and their activities possible. The number of strikes increased rapidly from 34 in 1972 to 501 in 1973, 357 in 1974, 241 in 1975, and 133 in $1976 .^{108}$ Also the number of political parties virtually exploded at the time of the first democratic national election in 1975 when 44 parties contested the 269 seats in the House. of Representatives and 22 achieved representation. ${ }^{109}$ Moreover, the free press became vocal while the other media turned. increasingly political. The democratic mood seemed all-embracing.

The major problem arose immediately after the election in 1975 as none of the 22 political parties were able to form a government on its own. This led to a coalition between 17 parties lasting only one year, when a new election was called. This came about as a result of heavy pressure from the military in order to prevent a socialist-oriented government, unacceptable to the military, from coming to power. The 1976 election was marred with violence claiming many lives. ${ }^{110}$ The socialist-oriented candidates of the New Force, Socialist and United Front parties together with student activists became the prime target of harassment, intimidation and violence by military-sponsored rightist groups. The result of heightened political tensions led to the electoral rejection of the socialist-oriented parties, and the formation of a new unstable coalition government contributed to the outbreak of the Thammasat massacre and the military coup of October 6, 1976. Democracy was again laid to rest as the 1974 constitution was revoked and parliament dissolved on the advocacy of the National Administrative Reform Council, appointed by the king, that the enemies of the nation were attempting to sabotage the stability of the kingdom, the throne and the national economy.

The pattern that followed the events prior to and after the period of open politics could also be observed during the period leading up to the "Black May" massacre in 1992. After Suchinda overthrew 
the Chatichai government in February 1991 in a bloodless coup the first move was to ban unions in state enterprises among the 200,000 employees.

As reported in the media about 50,000 people demonstrated on May 4, 1992, against the appointment of General Suchinda Kraprayoon as prime minister. The general, who toppled Prime Minister Chatichai in a 1991 coup, took over on April 7. The demonstration followed a rally which had taken place on April 20, with the participation of more than 50,000 people. ${ }^{111} \mathrm{~A}$ number of petitions were submitted to the king asking him to intervene. The rallies culminated in a big demonstration on May 17 with 200,000 demanding a revision of the constitution. ${ }^{112}$

American newspapers had some comments to make after the massacre in Bangkok. The United States had lived comfortably with military rule in Thailand for many decades. More recently, Washington had sought to display some of the same devotion to democratic values in Thailand that it had asserted in less strategic places; it suspended aid, for instance, after the coup. Still, the latest events caught the US government in the embarrassing circumstances of conducting joint military exercises with the Thai army.

An editorial in the International Herald Tribune stated that it was now up to the Thai leaders, especially King Bhumipol Adulyadej, to resolve the crisis by re-establishing democratic rule with the United States also playing a useful role. It had suspended most forms of cooperation with the regime. Now it needed to denounce General Suchinda in the strongest terms. Words matter in Thailand, "especially when Washington is their source."113 However, Japan the largest aid donor accounting for over three-quarters of aid to Thailand, did not consider suspending assistance. "We regard the Suchinda government as a legitimate, constitutional government", a senior official of Japan's foreign ministry said. ${ }^{114}$

On May 21 the King emerged from isolation to mediate what appeared to be a solution to the crisis which had cost at least 100 lives. But that number was still disputed at the end of 1992. As the Bangkok Post noted, "Gen. Suchinda may be out, but the military that supported him remains one of the key institutions of power in the country." 115 
In 1981 Morell and Chai-Anan asked: "Is Thailand ready for democracy as part of an institutional and attitudinal response to its identity crisis? In terms of alien Western structures and procedures alone, the answer remains rather firmly negative, nearly five decades after such forms were first introduced. Another set of superficial, irrelevant constitutions and formalistic elections of politicians to a remote, impotent but interventionist parliament in Bangkok surely cannot contribute very much to resolving Thailand's political crisis."

\section{Tentative Perspectives on State and Democracy in a Developmental Context}

The approach suggested in this article follows a state-centred line of argumentation by focusing on the dialectic of the processes of democracy and democratization combined with an eclectic view on internal and external determinants together with an emphasis on history. The case from Thailand, at least, confirms the initial theoretical consideration: there is no simple correlations between development and democracy. ${ }^{117}$

As far as the evolution of Thailand is concerned, it does not require clairvoyance to imagine in retrospect that the events of the last few years will result in a more realist interpretation of Bangkok's economic boom. There will be a sharp deterioration of the domestic budget and external trade balances, a resumption of foreign indebtedness, higher inflation, a move to "distort" domestic economic policy by adopting "nationalist" (i.e. anti-Chinese) policies. ${ }^{118}$ Sporadic nationalist reactions under past Thai regimes in this century made little long-lasting impact on communal feelings; today the only restrictive entry practices left seem to be at the Chullachomkhlao military academy, which continues excluding cadets born of first or second generation immigrants. The largely amicable ethnic coexistence, enhanced by frequent intermarriage, may not endure indefinitely, however. The rapacity that led to the wrecking of Thailand's forests and coastal resources usually carries 
a Chinese face, say Thai critics, in an allusion to the overwhelming Sino-Thai interests in the companies that have been involved in the destruction of Thailand's vast forests. Other local chauvinists see a Chinese hand behind the biggest banks and finance companies, prompting occasional mutterings from younger military officers. General Chaovalit, before becoming leader of the New Aspiration Party, occasionally made slightly veiled appeals to indigenous resentment vis-à-vis the Chinese; up to the end of the 1980s, however, these undercurrents normally had limited influence. ${ }^{119}$

The internal evolution can also be influenced by external fluctuations in global economic and political structures; the growing tendency towards protectionist mercantilism in the core states, i.e., Japan, United States and the EEC., can lead (as a response) to growing authoritarianism and less space for democratization from below. The state is likely to increase its capacity by manipulating and mobilizing the Thai people, as its elites, the triple alliance, run the country autonomously according to the concept of "the state shall lead, not serve the people."

With approximately 80 percent of a population of 55 million residing in rural areas, Thailand offers, indeed, a case of extreme dualism. ${ }^{120}$ Therefore support from the non-urban populace is at the heart of the struggle for political power. Whoever controls the rural vote gets political leverage over all other groups. At present, the bureaucrats within the Ministry of Internal Affairs and the military have that monopoly. ${ }^{121}$ It means that whoever is in control of the state apparatus has the power to handle rural forces. As Maisrikrod and Limsong conclude, "the dominance of the military-bureaucratic alliance over the businessmen-politicians is, unlike democracy, deeply rooted in Thailand's political culture." ${ }^{122}$ This interpretation is confirmed by Turton's extensive studies of power relation between the state and the rural population: even if there is a certain personal syncretism between military and other bureaucrats with the Sino-Thai business sector, "the military possess its own relative autonomy ... a momentum of its own somewhat hybrid, parasitic, 'secondary complex of predatory interests'."123

It is precisely this symbiotic relationship between a relatively autonomous military, civil bureaucrats in uniform, the state and the 
Sino-Thai business sector that essentially has to be broken before paternalist developmentalism fades away as the basis of the political system in Thailand. Furthermore, the external dimension must be taken into consideration to provide an understanding of the perception of this triple alliance, and its practice of favouring an authoritarian developmental policy, which is deemed necessary to enhance the export-driven growth strategy.

This is also the theme of the "later-comer" and "catch up" debate about developmental (soft) authoritarianism as a prerequisite for industrialization, economic growth and "modernization". Roman Szporluk concludes in his interesting contribution to the marxist versus nationalist controversy on economic policy that it is indeed true that the Third World today is "Listian in its outlook."124 The "young" Chalmers Johnson claimed in his book Revolutionary Change, which came out in the same period as Huntington's Political Order in Changing Societies that, "the process of social and economic change in the Third World was considered to produce a disintegrative interregnum which required a strong authoritarian rule to achieve political reintegration and economic development." ${ }^{.125}$ These two American political scientists' "advice," not only became reality in Thailand, as emphasized in this article, but was in fact institutionalized to cement paternalist developmentalism, and to cope with the so-called "demand overload" problem. It is precisely this built-in-heritage, the spontaneous popular movement toppled in May 1992.

The regime-form in Thailand cannot be defined as democracy or autocracy, neither in functionalist terms nor in the idealist form in Dahl's version. This is so not only because of the role of the military but also on account of the rules and regulations as stated in the law implemented by the Sarit regime in the 1950s. Rather, the regimeform can best be characterized as an authoritarian developmental state, conditioned by the internal cleavage in the authoritarian triple alliance between the predominantly Chinese bourgeoisie, the civil and military bureaucracy, and the impact of external forces (primarily American) on these two groups.

This specific relationship between the state and the macroeconomic actors at the national and international level is reflected 
in the shifting balance of power in the triple alliance and has been the underlying cause for the way state power and state form has been created in Thailand. It does not, on the other hand, connote any causal relationship between the regime-form, type of state, state power, state form and the question of democratization from below. In Thailand, as in many other near-NICs, it means the subordination and the exclusion of any political forces from below in the process of democratization. Not only on the political level but also with regard to economic and social rights. This means, finally, that the four structural capacities of the state in Thailand have a great impact on increasing the relative autonomy of the state, which is the most important prerequisite for developmentalism and authoritarian policies. As long as the military more or less controls these capacities, the stability of economic policy and non-democratic developmental practice are secured for years to come. Constitutions come and constitutions go, but in the end, the military and the bureaucracy have the final say. Therefore, as we have seen in the months after the military regime was toppled in May 1992, the new care-taker Anand and his democraticly elected followers, have not only tried to get the army back to the barracks, but out of the bureaucracy, lucrative government monopolies, parastals and business, legal and illegal activities, as well. It remains to be seen whether the newly elected democratic government will be able to change the structures of the state bureaucracy. As an observer pointed out after the February 1991 coup, as a preliminary measure to break with authoritarian rule, "the next government needs to ponder the relocation of major military units out of Bangkok, and launch a two-pronged effort to divide and co-opt the military. This could be done by actively soliciting the loyalty and respect of officers who command key regiments."126

The final question is not, as mistakenly claimed by some observers, who will carry out the "historical mission" (i.e. the development of democracy) in Thailand. But rather, since democracy is such a relative concept, the most crucial question has to be "whose democracy and under whose hegemony". The events of the infamous Black May incident should not lead to the conclusion that the role of the military in Thai politics and state affairs is over. In fact, as argued in this paper, history has shown 
the necessity for strong government - with or without the military - in guiding the economy and achieving sustained high economic growth.

\section{Johannes Dragsbaek Schmidt is a Research Fellow at the International Studies Center, Aalborg University, Denmark.}

\section{NOTES}

1 I would like to thank Kjeld Erik Brødsgaard, Jacques Hersh and three anonymous referees for their patience and constructive criticisms.

2 Since the 1932 coup that formally ended the absolute monarchy, Thailand has had 19 coups and 14 different constitutions.

3 See John Naisbitt and Patricia Aburdene, Megatrends 2000: Ten New Directions for the 1990s (New York: W. Morrow and Co., 1990).

4 International Herald Tribune, December 5, 1990.

5 Bruce McFarlane, "Growth and Cycles in Southeast Asian Development," Journal of Contemporary Asia, Vol. 18, No. 2 (1988), pp. 121-124.

6 Chris Dixon, South East Asia in the World-Economy (Cambridge, New York: Cambridge University Press, 1991), p. 14.

7 Ibid.., p. 181.

8 Naisbitt and Aburdene, Megatrends 2000, p. 197

9 Bangkok Post, September 21, 1988.

10 M.R. Kasem S. Kasemsri, "Thai-U.S. Relations at a Critical Juncture," in Ansil Ramsay and Wiwat Mungkandi, eds., Thailand-U.S. Relations: Changing Political, Strategic, and Economic Factors (Berkeley: Institute of East Asian Studies, University of California, 1988), pp. 8-9.

11 Chalmers Johnson, MITI and the Japanese Miracle (Stanford: Stanford University Press, 1982); and Chalmers Johnson, "The nonsocialist
NICs: East Asia," International Organization, Vol. 40, No. 2 (Spring 1986).

12 The concept defining the Japanese model was first introduced by Chalmers Johnson, MITI and the Japanese Miracle, pp. 3-35 and pp. 305-324.

13 Chalmers Johnson, Laura D'Andrea Tyson, and John Zysman, Politics and Productivity: How Japan's Development Strategy Works (Berkeley: Ballinger Publishing Co., 1989), p. xvi.

14 Gordon White, ed., Developmental States in East Asia (Houndsmills, Basingstoke and Hampshire: MacMillan Press 1988); Robert Wade, Governing the Market, Economic Theory and The Role of Government in East Asian Industrialization (Princeton, New Jersey: Princeton University Press, 1990).

15 See Alfred Stepan, Democratizing Brazil: Problems of Transition and Consolidation (Oxford: Oxford University Press, 1989).

16 This section is based on my M.A. thesis, Johannes Schmidt, "Stat og Demokrati i Thailand: Vindere og Tabere $i$ den Paternalistiske Udviklingsstat," M.A. thesis, (Aalborg University Center, 1991) (unpublished, in Danish). See also Donald Crone, "State, Social Elites, and Government Capacity in Southeast Asia," World Politics, Vol. L., No. 2 (January, 1988); Sue-Hoon Lee, State-Building in the Con- 
temporary World, IFES Third World Series, No. 2 (Boulder, Colorado: Westview Press, 1988); Grit Permtanjit, Political Econorny of Dependent Capitalist Development: Study on the Limits of the State to Rationalize in Thailand (Bangkok: CUSRI, 1982).

17 See John F. Embree, "Thailand - A Loosely Structured Social System," American Anthropologists, Vol. 50, No. 2 (April/June 1950), pp. 181-193; and Frank Golay et al., Underdevelopment and Economic Nationalism in Southeast Asia (Ithaca and London: Cornell University Press, 1969).

18 Chai-Anan Samudavanija, "Thailand: A Stable Semi-democracy," in Larry Diamond, Juan Linz, and Seymour Martin Lipset, eds., Democracy in Developing Countries: Asia, Vol. 3 (Boulder, Colorado: Lynne Rienner, 1989), p. 305.

19 Norman Jakobs, Modernization without Development (New York: Praeger Publishers, 1971), pp. 3-4.

20 Johnson et al., Politics and Productivity, p. 187.

21 Ibid.

22 Jakobs, Modernization without Development, p. 4.

23 WiratWattanasiritham, Pak Tongsom et. al., "Thailand Socio-Economic .Development Planning," in Warin Wonghanchao and Yukio Ikemoto, eds., Economic Development Policy in Thailand (Tokyo: Institute of Developing Economies, 1988), p. 38. For a detailed discussion of the consequences see, James C. Ingram, Economic Change in Thailand Since 1850-1970 (Stanford: Stanford University Press, 1971); and Akira Suehiro, Capital Accumulation and Industrial Development in Thailand (Bangkok: CUSRI, 1985).

24 Lucien M. Hanks, "The Yuan or Northern Thai," in John McKinnon and Wanat Bhruksasri, eds., Highlanders of Thailand (Kuala Lumpur: Oxford University Press, 1983), p. 101.

25 Benedict Anderson, Imagined Communities: Reflections on the Origin and Spread of Nationalism (London: Verso, 1983), p. 94.

26 Literally Sakdina means power (rank and honour) in or over land (especially irrigated rice fields). The term Sakdina refers to a hierarchical system which has developed in the Ayuthaya period (1350-1770) and the early Bangkok periods (1782 to around 1900). Some scholars, Marxist and otherwise, use the term interchangeably with Thai feudalism, although one could argue that the early Sakdina had more in common with "the Asiatic Mode of Production" developed by Marx and later revised by Wittfogel. See Chatthip Narsupha, "The Ideology of Holy Men's Revolts," in Shingeharu Tanabe and Andrew Turton, eds., History and Peasant Consciousness in Southeast Asia, Senri Ethnological Studies, No. 13 (Osaka: 1984), pp. 128-129.

27 In particular the two-class system with Nai (Master) and Phrai (Subject). For a comprehensive discussion see, Chairat Charoensino-larn, Understanding Postwar Reformism in Thailand (Bangkok: Duang Kramol, 1988), pp. 132-135.

28 Thak Chaloemtiarana, Thailand: The Politics of Despotic Paternalism (Bangkok: Social Science Ass. of Thailand/Thai Khadi Institute, Thammasat University, 1979), pp. xvi-xviii.

29 Prudisan Jumbala, "Political System and Nation-Building in Thailand," research paper presented at the workshop on "Political System and Nation-Building in ASEAN" organized by the Department of Political Science, National University of Singapore, January 23-25, 1986.

30 David K. Wyatt, Thailand: A Short History (New Haven \& London: Yale University Press, 1984), p. 219.

31 See Fred Riggs, Thailand: The Modernization of a Bureaucratic Polity (Honolulu: East-West Center Press, 1966); and William Skinner, Chinese in Thailand: An Analytical History 
(Ithaca \& New York: Cornell University Press, 1957).

32 Anuj Arbhabhirama, "Observations on Bureaucratic Democracy in Thailand," Asian Review: Journal of Asian Studies, Vol. 1 (1987), p. 31.

33 Mike Douglass, Regional Integration on the Capitalist Periphery: The Central Plains of Thailand (Hague: Institute of Social Studies, 1984), p. 177.

34 James Clad, Behind the Myth: Business, Money and Power in Southeast Asia (London: Unwin Hyman, 1989), pp. 110-111.

35 Kevin Hewison, Bankers and Bureaucrats: Capital and the Role of the State in Thailand, Monograph Series 34 (New Haven, Connecticut: Yale Center for International and Area Studies, 1989); and Stanley J. Tambiah, World Conqueror and World Denouncer: A Study of Buddhism and Polity in Thailand Against a Historical Background (Cambridge: Cambridge University Press, 1976).

36 Andrew Turton, Production, Power and Participation in Rural Thailand: Experiences of Poor Farmers Groups (Geneva: UNRISD, 1987); Victor P. Karunan, A History of Peasant Movements in Thailand and the Philippines, Vol. 1: If the Land Could Speak, It Would Speak for Us ... (Hong Kong: Plough Publ., 1984); Benedict Anderson, "Murder and Progress," New Left Review, No. 181 (1990). See also Peter Vandergeest, "Siam into Thailand: Constituting Progress, Resistance, and Citizenship," Ph.D. dissertation, Cornell University, 1990, pp. 435-444; and Kevin Hewison, "Culturalism and the Analysis of Politics," in Kevin Hewison, Power and Politics in Thailand (Manila \& Wollongong: Journal of Contemporary Asia Publishers, 1989), p. 25.

37 Andrew Turton, "Limits of Ideological Domination and the Formation of Social Consciousness," in Tanabe and Turton, eds., History and Peasant Consciousness in Southeast Asia, p. 21.
38 Chairat, Understanding Postwar Reformism, pp. 142-143.

39 Suchart Prasith-rathsint, ed., Thailand's National Development: Policy Issues and Challenges (Bangkok: TURA, 1987), p. 7.

40 See Clad, Behind the Myth, p. 116.

41 Charles F. Keyes, Buddhist Kingdom as Modern Nation-State (Boulder and London: Westview Press, 1987), p. 169.

42 Frederic C. Deyo, Beneath the Miracle: Labor Subordination in the New Asian Industrialism (Berkeley: University of California Press, 1989), p. 189.

43 See e.g. Chairat, Understanding Postwar Reformism, pp. 177-183; and Thak, Thailand: The Politics of Despotic Paternalism. The following quotation is a statement from Field Marshal Sarit (1957-1969): "No matter how advanced modern political science is, there exists one crucial principle in traditional Thai government and administration that can never be overlooked. This very principle, which is still impeccable and should be utilized, is that of paternalism (Phoo Ban, Phoo Muang). A Nation is like a large family. The governor, the provincial secretary and the district officer are family heads within the administrative hierarchy. Administrators must always keep in mind that people under their jurisdiction are not outsiders but members of the same family; they are siblings and relatives. Their wellbeing, happiness, and grievances are family matters and must be taken care of attentively", ibid., pp. 216-217.

44 Prudhisan, "Political System and Nation-Building in Thailand," pp. 1213.

45 Suehiro, Capital Accumulation and Industrial Development in Thailand, pp. 2-37.

46 Anuj, "Observations on Bureaucratic Democracy in Thailand," p. 47.

47 "Those who were impatient were the Western-educated military and civilian bureaucrats. In the absence of a sizable middle class, a large and 
strong bureaucracy became the locus of power in the new constitutional arrangements", argues Chai-Anan in "Thailand: A Stable Semi-Democracy," pp. 306-307.

48 John Girling, Thailand: Society and Politics (Ithaca \& London: Cornell University Press, 1981), p. 60.

49 Thainan Nakata, The Problems of Democracy in Thailand: A Study of Political Culture and Socialization of College Students (Bangkok: PRAEPITTAYA Int., 1975), p. 55.

50 Thak, Thailand: The Politics of Despotic Paternalism, pp. 140-141.

51 Ibid.., pp. 167-168.

52 Chairat, Understanding Postwar Reformism, p. 131.

53 Damrong Thandee, Politics of Policy Implementation: A Case Study of Rural Development (Bangkok: CUSRI, 1985), p. 62.

54 Thak, Thailand: The Politics of Despotic Paternalism, p. 222.

55 For information on the various arrests, abolishing of labour acts, etc., see Suchit Bunbingkarn, "Political Institutions and Processes," in Somsakdi Xuto, ed., Government and Politics in Thailand (Singapore: Oxford University Press, 1987).

56 Hewison, Bankers and Bureaucrats, $\mathrm{p}$. 122.

57 Suehiro, Capital Accumulation and Industrial Development in Thailand, pp. 3-25. Note the assimilation of the Chinese was part of Sarit's thaification programme but it is quite difficult to measure the succes of this programme even today. This article argues, that the thaification programme was a forced integration but not assimilation. Therefore the term Sino-Thai bourgeoisie is used synomously with the Chinese.

58 This is the argument made in a number of studies by Riggs, Thailand: The Modernization of a Bureaucratic Polity; David Morell and Chai-Anan Samudavanija, Political Conflict in Thailand: Reform, Reaction, Revolution (Cambridge, Massachusets: Oelschlager, Gunn \& Haia Inc., 1981); David Wilson, Politics in
Thailand (Ithaca \& London: Cornell University Press, 1962); Clark D. Neher, "The Foreign Policy of Thailand," in C.D. Neher et al., The Political Economy of Foreign Policy in Southeast Asia (London: Macmillan, 1990); and Joseph J. Wright Jr., The Balancing Act: A History of Modern Thailand (Oakland, California: Asia Books \& Pacific Rim Press, 1991).

59 Douglass, Regional Integration on the Capitalist Periphery, p. 171.

60 Brewster Grace, A Note on Thailand, American University Field Staff Reports, Southeast Asia Series, Vol. 22, No. 4 (1974), p. 5.

61 Girling, Thailand: Society and Politics, p. 92.

62 Sukhumbhand Paribatra, "Thailand and Its Indochinese Neighbours: The Enduring Logic," in Lau Teik Soon and Leo Suryadinata, eds., Moving Into the Pacific Century: The Changing Regional Order in the Asia-Pacific (Singapore: Heinemann Asia, 1988), pp. 142-143.

63 Peter F. Bell, "Cycles of Class Struggles in Thailand," Journal of Contemporary Asia, Vol. 8, No. 1 (1978), p. 51; see also Robert J. Muscat, Thailand and the United States: Development, Security and Foreign Aid (New York: Columbia University Press, 1990), p. 262.

64 Surachart Bamrungsuk, United States Foreign Policy and Thai Military Rule 1947-1977 (Bangkok: Duang Kramol, 1988), p. 44; David Elliott, Origins of Military Rule (London: Zed Press, 1978). Muscat, however, notes that in some respects the aid programs in Taiwan and Thailand were similar. See Muscat, Thailand and the United States, pp. 8 and 18.

65 There is a growing literature on Japan's ascendency over East Asia. See for example "Sayonara, America Japan is building an Asian Yen Bloc - and the United States is the Big Loser," Newsweek, August 5, 1991, pp. 22-29; and "Building Roads for Japanese Investment;" and "The Thailand Cultural Center: Better to Call It Japanese?," AMPO: Japan 
ASIA Quarterly Review, Vol. 21, No. 4 (1990), pp. 38-42; see also William R. Nester, The Foundation of Japanese Power: Continuities, Changes, Challenges (London: Macmillan 1990), pp. 376-377; and William R. Nester, Japan's Growing Power over East Asia and the World Economy: Ends and Means (London: Macmillan, 1990), pp. 112-124.

66 Masashi Nishihara, "Japanese Role in the Pacific Basin Coalition," in Lau and Leo, eds., Moving Into the Pacific Century, pp. 86-87.

67 Eero Palmujoki, "Diplomacy over the Kampuchean Question," Southeast Asian Affairs 1990 (Singapore: ISEAS, 1991), p. 140.

68 Khatharya Um, "Thailand and the Dynamics of Economic and Security Complex," Contemporary Southeast Asia, Vol. 13, No. 3 (December, 1991), p. 248.

69 Examples of clashes are reported in Clark D. Neher, "Change in Thailand," Current History (March, 1990), p. 102. See also Scott R. Christensen, "Thailand in 1989: Consensus at Bay," Asian Survey, Vol. X-XX, No. 2 (February, 1990), pp. 184-185.

70 Muscat, Thailand and the United States, p. 262 and pp. 268-271. See also David Wurfel, "Conclusion," in David Wurfel and Bruce Burton, eds., The Political Economy of Foreign Policy in Southeast Asia (London: Macmillan, 1990), p. 302.

71 Grit, Political Economy of Dependent Capitalist Development, p. 108.

72 Ibid.., p. 64; see also Muscat, Thailand and the United States, pp. 268-269.

73 Ingram, Economic Change in Thailand Since 1850-1970, p. 231 and Robert J. Muscat, who notes that the amount of American aid in the forty-year period 1946-1986 cumulated to large amounts than any African recipient with the exceptional (Egypt) Muscat, Thailand and the United States, p. 30.

74 See Richard Robison, Richard Higgott, and Kevin Hewison, "Crisis in Economic Strategy in the 1980s:
The Factors at Work," in R. Robison et al., Southeast Asia in the 1980s: The Politics of Economic Crisis (Sydney: Allen \& Unwin, 1985), p. 7.

75 Warin Wonghanchao and Jeerasak Pongpissanupichit, "Contribution of Direct Foreign Investment to the Thai Economy," in Asia Pacific Economies: Promisses and Challenges, Research in International Business and Management, Vol. 6, Part B, (1988), p. 250.

76 Pasuk Pongchaipit, "Technocrats, Businessmen, and Generals: Democracy and Economic Policy-Making in Thailand," in Andrew J. MacIntyre and Kanishka Jayasuriya, eds., The Dynamics of Economic Policy Reform in South-East Asia and the South-West Pacific (Singapore: Oxford University Press, 1992), pp. 16, 30.

77 Warin Wonghanchao, Thailand in the 21st Century: Economic Prospects (Bangkok: SEPFU, Chulalongkorn University, 1988), p. 7.

78 Nester, Japan's Growing Power over East Asia and the World Economy, pp. 112-124.

79 Walter Arnold, "Japan's Relations with China since 1978," in Kathleen Newland, ed., The International Relations of Japan (London: Macmillan 1990), p. 123.

80 Somsak Tambunlertchai and Umphon Panachet, "Foreign Direct Investment in ASEAN," in Soon Lee Ying, ed., Foreign Direct Investment in ASEAN (Kuala Lumpur: Malaysian Economic Association, 1990), p. 65.

81 Kevin Hewison, "The State and Capitalist Development in Thailand," in Robison et. al., eds., Southeast Asia in the 1980s, p. 60.

82 It must be emphasized, however, that the organization was indeed explosive: for accounts on workers organization, see Chairat, Understanding Postwar Reformism, p. 164; for farmers and students organizations, see Suchit Bumbongkarn, "The Student Uprising in October 1973 and 1976", in Yogesh Atal, ed., Dynamics of Nation-Building, Communication in Crisis, RUSHASP 
Series on Occasional Monographs and Papers 13, Vol. II (Bangkok: UNESCO, 1985), p. 297; for the Thai petty bourgeoisie organizations, see Prudhisan Jumbala, "Interests and Pressure Groups", in Somsakdi, ed., Government and Politics in Thailand, pp. 113-125; for the parliamentary and constitutional developments, see Chai-Anan, "Thailand: A Stable Semi-democracy," pp. 313-315, and finally for political party organizations see, Kramol Tongdhamachart, Toward a Political Party Theory in Thai Perspective, Occasional Paper, No. 68 (Singapore: ISEAS, 1982), pp. 19-40.

83 Turton, "Limits of Ideological Domination and the Formation of Social Consciousness," p. 99. For a view opposite to Turton's, see Suchit Bunbongkarn, The Military in Thai Politics, 1981-86 (Singapore: ISEAS, 1987).

84 Mingsarn Sannkarn Kaossard and Ams Israngkura, "Industrial Policies in Thailand," in Warin Wonghanchao \& Yukio Ikemoto, eds., Economic Development Policy in Thailand, p. 157.

85 Pasuk, "Technocrats, Businessmenn, and Generals," p. 26.

86 Dixon, South East Asia in the WorldEconomy, p. 206.

87 The following paragraph relies heavily on Grit, Political Economy of Dependent Capitalist Development, and Chairat, Understanding Postwar Reformism, pp. 156-201.

88 Suntaree Komin, "Social Dimensions of Industrialization in Thailand," Regional Development Dialogue, Vol. 12, No. 1 (Spring 1991), pp. 116-117. For an important contribution to the crucial problem of the consequences of government de-emphasizing income distribution, see Yukio Ikemoto, Income Distribution in Thailand: Its Changes, Causes and Structure (Tokyo: Institute of Developing Economies, 1991), pp. 150-154.

89 Crone, "States, Social Elites, and Government Capacity in Southeast Asia."
90 Derek Tonkin, "The Art of Politics in Thailand," Asian Affairs, Vol. XXI, Part III (October, 1990), p. 291; John Girling, "Thailand in Gramscian Perspective," Pacific Affairs, Vol. 57, No. 3 (1984), p. 395.

91 Chai-Anan Samudavanija, "The Bureaucracy," in Somsakdi, ed., Government and Politics in Thailand, $\mathrm{p}$. 95.

92 Sukhumband Paribatra, Thailand: Defence Spending in Southeast Asia (Singapore: ISEAS, 1987), p. 82.

93 David Feeny, The Political Economy of Productivity: Thai Agricultural Development, 1880-1975 (Vancouver and London: University of British Columbia Press, 1982), pp. 113-125.

94 There are two related consequences of the implementation of the rice premium policy: 1) the stabilization of the domestic price of rice and 2) the diversification of Thai agriculture. Simply speaking, the rice premium is an export tax on rice. Rice exporters are required to pay a certain levy to the government for each ton of rice being exported.

95 A striking example is the fact that Thailand is the site of the world's third largest Japanese embassy and Thailand was the seventh largest recipient of Japanese ODA in 1969-' 79, but between 1979 and 1986 it became the second largest recipient in cumulative terms. See Chaiwat Khamchoo, "Japan's Role in Southeast Asian Security in the 1990s," Asian Review, Vol. 4 (1990), pp. 60-61.

96 See Pornpirom Iamtham, "The Student-Led Democratic Movement after the 14 October 1973 Incident and Its Relations with the Communist Party of Thailand," Asian Review, Vol. 1 (1987), pp. 9-11.

97 Turton, Production, Power and Participation in Rural Thailand, p. 31. See also Shane P. Tarr, "The Nature of Military Intervention in the Countryside of Surat Thani," Bulletin of Concerned Asian Scholars, Vol. 23, No. 3 (1991), pp. 46-50. 
98 This paragraph relies heavily on Far Eastern Economic Review, June 27, 1991.

99 Sukhumband, Thailand: Defence Spending in Southeast Asia, p. 84 and pp. 90-102.

100 Wilson, Politics in Thailand, p. 280.

101 Asia Yearbook 1974, Far Eastern Economic Review, (1974), p. 309.

102 Prudhisan, "Political System and Nation-building," p. 38.

103 Suchit, "The Student Uprising in October 1973 and 1976", p. 297.

104 Asia Yearbook 1974, estimated 350 killed and more than 1000 wounded of which 90 percent were students, p. 304 .

105 Girling, Thailand: Society and Politics, p. 188.

106 Pornpirom, "The Student-Led Democratic Movement," p. 7 and p. 11.

107 Grit, Political Economy of Dependent Capitalist Development, p. 170.

108 Viggo Brun, "Workers and Labor Unions in Thailand," AMPO, (Part I and II), Vol. 14, Nos. 3-4 (1982), pp. 51-57.

109 Kramol, Toward a Political Party Theory in Thai Perspective, pp. 19-40.

110 Morell and Chai-Anan, Political Conflict in Thailand, p. 262. See also Anderson who notes: "Most notoriously was the Red Gaurs, many of them ex-mercenaries from the CIA's 'secret army' in Laos, who operated at the behest of the dominant clique in the ISOC of the armed forces; but also the Village Scouts, right-wing vigilante groups under the aegis of the Palace." Anderson, "Murder and Progress," p. 43.

111 International Herald Tribune, May 5, 1992.

112 The Guardian, May 18, 1992.

113 International Herald Tribune, May 18, 1992.

114 Ibid.., May 21, 1992.

115 Bangkok Post, May 26, 1992.

116 Morell and Chai-Anan, Political Conflict in Thailand, p. 313.

117 For this kind of argument, see also Stephen Haggard, Pathways From the
Periphery: The Politics of Growth in the Newly Industrializing Countries (Ithaca \& London: Cornell University Press, 1990), p. 257.

118 Clad, Behind the Myth, pp. 123-124. In addition, Clad refers to FEER correspondent Paisal Sricharatchanya in Bangkok who mentions that "The Sino-Thais have emerged as the dominant economic group, controlling almost all key business sectors and are the predominant student group in the elite Thai universities Chulalongkorn and Thammasat. Up to 50 percent of Bangkok's population is estimated to be ethnically Chinese nowadays," Far Eastern Economic Review, February 18, 1988.

119 Ibid.., pp. 150-151.

120 See John P. Lewis and Devesh Kapur, "An Updating Country Study: Thailand's Needs and Prospects in the 1990s," World Development, Vol. 18, No. 10 (1991), p. 1364 and p. 1373.

121 Surin Maisrikrod and Suparra Limsong, "Thailand Deconstructing the Coup," Pacific Research, (August 1991), p. 8.

122 Ibid.., p. 8.

123 Andrew Turton, "Local Powers and Rural Differentiation," in Gillian Hart, Andrew Turton and Benjamin White, Agrarian Transformation: Local Processes and the State in Southeast Asia (Berkeley \& Los Angeles: University of California Press, 1989), p. 73.

124 Roman Szporluk, Communism and Nationalism: Karl Marx Versus Freidrich List (New York \& Oxford: Oxford University Press, 1988), p. 237. The most striking example is of course Japan's ODA policy which intention has been called "comprehensive security" and consists of three main points: 1) to secure the supply of natural resources, 2) to keep the external environment stable and peaceful, 3) to provide profitable official means for the domestic private sector. See Motoko Shuto, "ODA in Japan's Foreign 
Policy: Changes, Characteristics and Prospects," Asian Review, Vol. 4 (1990), p. 43.

125 Chalmers Johnson, Revolutionary Change (Boston: Little Brown, 1966), quoted from R. Higgott, R. Robison \& K. Hewison, Theories of
Development and Underdevelopment: Implications for the Study of Southeast Asia (London: Routledge \& Keegan, 1985), p. 21 and p. 54 nt. 24.

126 Thitinan Pongssudhirak, "Avoid the 18th coup," Far Eastern Economic Review, 4 April, 1991. 